\title{
Synthesis and Evaluation Antibacterial Activity of Some New Substituted 5-Bromoisatin Containing Five, Six Heterocyclic Ring
}

\author{
Suaad M. H. Al-Majidi \\ Huda J. A. Al-Adhami \\ Department of Chemistry, College of Science, University of Baghdad, Baghdad, Iraq
}

E-mail: hudajja@yahoo.com

Received 17/9/2015

Accepted 20/12/2015

(c)
NoDerivatives 4.0 International Licens

\begin{abstract}
:
This research includes the synthesis of some new different heterocyclic derivatives of 5-Bromoisatin. New sulfonylamide, diazine, oxazole, thiazole and 1,2,3-triazole derivatives of 5-Bromoisatin have been synthesized. The synthesis process started by the reaction of 5-Bromoisatin with different reagents to obtain schiff bases of 5Bromoisatin intermediate compounds $(1,8,19)$ by using glacial acetic acid as a catalyst in three routes. The first route, 5-Bromoisatin reacted with $p$ aminosulfonylchloride to product compound(1), then converted to sulfonyl amide derivatives(2-7) by the reaction of compound(1) with different substituted primary aromatic amine in absolute ethanol. The second route includes the reaction of 5Bromoisatin reacted with ethyl glycinate to give 5-bromo-3-(Ethyl imino acetate)-2oxo indole(8), which undergo react with hydrazine hydrate $80 \%$ to obtain hydrazine derivatives(9) that react with different acid anhydrides to obtain diazine derivatives(10-14). Also compound(8) reacts with urea and thiourea to give compounds $(15,16)$ which undergo cyclization with $p$-bromophenacylbromide in absolute ethanol as a solvent to obtain oxazole (17) and thiazole (18), respectively. The third route included the reaction of 5-Bromoisatin with $p$-phenylenediamine in ethanol to obtain compound(19) which is converted to new substitutes 1,2,3-triazole derivatives $(22,23)$ by diazotation of compound(19) and treating the resulted salt(20) with sodium azid, then acetylaceton or ethylacetoacetate, respectively. Newly synthesized compounds were identified by spectral methods. (FTIR, ${ }^{1} \mathrm{H}-\mathrm{NMR},{ }^{13} \mathrm{C}$ NMR) and measurements of some of its physical properties and also some specific reactions. Furthermore the effects of the synthesized compounds were studied on some strains of bacteria.
\end{abstract}

Key words: 5-Bromoisatin, Sulfonylamide, Diazine, Oxazole, Thiazole, 1,2,3Triazole, antibacterial.

\section{Introduction}

Isatin and its derivatives have a broad range of important biological, pharmacological and medicinal properties. It has discontinuous and 
distinct distribution of peripheral tissue and body fluid and isatin conjoint site that are widely distributed and widely used as starting materials for the synthesis of broad range of heterocyclic compounds and as substrates for drug synthesis[1-3]. Sulfonamides are one of the oldest groups of the drugs; they have been in clinical use for over 70 years. It plays an important role in medicinal chemistry and it is used as anticancer drugs because it contains the sulfonamide subunit[4]. Owing to its wide application as antimicrobial[5], antibacterial[6], antioxidant[7], anticonvulsant, antipsychotic, antihypertensive, anti-inflammatory, diuretic, hypo-glycemic[8-10]. Sulfonamides are an essential class of antibacterial drugs used in medicine and veterinary practice[11]. Sulfa drugs are widely used in the treatment of infections, especially for patients intolerant to antibiotics. The vast commercial success of these medicinal agents has made the chemistry of sulfonamides become important in pharmaceutical sciences[12]. Pyridazine nucleus has been extensively studied as new and selective medicinal agents and as drugs acting on the system of cardiovascular; its derivatives can be used in the prostate cancer[13]. The biological activities of Its derivatives are antibacterial[14], antimicrobial[15], antifungal[16], antiinflammato-ry activities[17] antimala, analgesic and antipyretic[18]. Also developed newly pyridazine derivatives for the treatment of chronic lower back pain, chromic inflammatory pain associated with csteo arthritis and rheumatoid arthritis[19]. Oxazole and its derivatives used in industrial purposes and increased interest in their application of chemistry[20]. Thiazole derivatives are used as sedative, cardiotonic, anesthetic and many other applications of thiazole derivatives like cosmetics (sunscreens) or in liquid crystals[21]. 1,2,3-Triazoles are mainly useful in synthetic organic chemistry due to their variety of interesting biological activities like antibacterial, anticancer, antiviral,analgesic,

fungicidal activity[22]. Triazoles have also a wide variety of interesting drugs[23].

\section{Materials and Methods \\ Materials and Instruments}

Chemicals used in this work are supplied from BDH, Fluka, Merck and Sigma Aldrich companies and used without further purification. Melting points were uncorrected and registered via digital Stuart scientific SMP3 melting point device .Thin layer chromatography (TLC) used to check purity and homogeneity of synthesis compounds. FTIR spectra of the compounds in the (4000-600) $\mathrm{cm}^{-1}$ spectral range were recorded on SHIMAZU FTIR-8400 Fourier transform Infrared spectrophotometer using $\mathrm{KBr}$ discs. ${ }^{1} \mathrm{HNMR}$ and ${ }^{13} \mathrm{CNMR}$ spectra were recorded on Bruker $600 \mathrm{MHz}$ in Germany, instrument using TMS as internal reference and DMSO$\mathrm{d}_{6}$ as a solvent.

\section{Synthesis of 5-bromo-3-( $p$ - iminophenyl enesulfonylchloride)-2- oxo indole(1)[24]}

In round bottomed flask were placed $(2 \mathrm{~g}, \quad 0.0088 \mathrm{~mol})$ of 5-Bromoisatin(Indole-2,3-dione) were placed with $(1.70 \mathrm{~g}, \quad 0.0088 \mathrm{~mol}) \quad p$ anilinesulphonylchloride in (9ml) dimethylformamide and 4-5 drops of glacial acetic acid, refluxed the mixture for $(12 \mathrm{hrs}$.). The precipitate was filtered off, washed with water, dried and recrystallized from ethanol. Physical properties and FTIR spectral data of compound (1) are listed in Table (1).

\section{Synthesis of 5-bromo- 3- [p-imino( phenylenesulfonyl subutituted amine)]-2-oxo indole(2-7)[25]}


The $2^{\text {nd }}$ National Conference of Chemistry

substituted primary aromatic amines $(0.0025 \mathrm{~mol})$ are dissolved in $(7 \mathrm{ml})$ absolute ethanol, place this solution in $50 \mathrm{ml}$ round bottomed flask then $(1 \mathrm{~g}$, 0.0025 mol.) of compound (1) was added in partition with stirring and trying to keep the temperature below $40^{\circ} \mathrm{C}$. The mixture was refluxed for $(3$ hrs.) with continuous stirring after that the mixture was cooled to room temperature and poured into excess cold water with stirring; the obtained precipitate was filtered, washed with water for several times and dried. The product was purified by recrystallization from methanol. Physical properties and FTIR spectral data of the products are listed in Table (1).

Synthesis of 5-bromo-3-(Ethyl imino acetate)-2-oxo indole(8)[24]

A solution of 5-Bromoisatin(Indole2,3-dione $) \quad(2 \mathrm{~g}, \quad 0.0088 \mathrm{~mol}) \quad$ with $(1.175 \mathrm{~g}, 0.0088 \mathrm{~mol})$ ethyl glycinate in (10ml) (DMF) dimethylformamide and 4-5 drops of glacial acetic acid. The mixture was refluxed for (12 hrs.), trying to keep the heat of the range at $(50-60)^{\circ} \mathrm{C}$ The formed precipitate may be cooled off before pouring into crushed ice, filtered with recrystalization from ethanol-water. Physical properties and FTIR spectral data of compound (8) are listed in Table (2).

Synthesis of 5-bromo-3-(imino acetohydrazide)-2-oxo indole(9)[26]

In round bottomed flask $50 \mathrm{ml}$ was placed $(2 \mathrm{~g}, 0.0061 \mathrm{~mol})$ of compound (8), dissolved in (10ml) dimethylformamide then added excess of hydrazine hydrate $80 \%(0.007 \mathrm{~mol})$ with continuous stirring, the solution was refluxed for $(7 \mathrm{hrs}$.). The resulted, cooled off before pouring into crushed ice. The precipitate was filtered, washed by distilled water and dried then was purified by recrystallization from ethanol. Physical properties and FTIR spectral data are listed in Table (2).

Synthesis of 5-bromo-3-[imino aceto (hexahydrodiazepine-3,7-dione)]-2- oxo indole(10), 5-bromo-3[iminoaceto(tetra hydropyridazin-3,6dione)]-2-oxo indole (11), 5-bromo-3[iminoaceto (6-nitro- 1,2dihydrophtalazin-3,10-dione)]-2-oxo indole(12), 5-bromo-3[iminoaceto(1,2-dichloro pyridiazin3,6-dione)]-2-oxo indole(13) and 5bromo-3-[imino aceto(1,2-dihydro itaconic-3,6-dione)]-2-oxo indole(14)[27]

A mixture of hydrized derivative(9) (0.5 g, 0.0017 mol.) with (Glutaric anhydride, succinic anhydride, 4nitrophthalic anhydride, 2,3dichloro malic anhydride and itaconic anhydride) respectively ( $0.0017 \mathrm{~mol}$.) in $(10 \mathrm{ml})$ of glacial acetic acid was refluxed for ( 6-8 hrs), then cooling mixture by adding it to ice bath product the obtain precipitate which was filtered and recrystallized from suitable solvent. Physical properties and FTIR spectral data of compounds (10-14) are listed in Table (2).

Synthesis of 5-bromo-3-[(imino aceto) urea]-2-oxo indole-[15] and 5-bromo3-[( imino aceto ) thiourea ]-2-oxo indole(16)[27]

In $50 \mathrm{ml}$ round bottomed flask, a mixture (1 g, $0.0031 \mathrm{~mol})$ of compound (8) with (urea, thiourea) were placed respectively $(0.0031 \mathrm{~mol})$ and $(0.25 \mathrm{~g}$ $, 0.0031 \mathrm{~mol})$ of sodium acetate in $(8 \mathrm{ml})$ absolute ethanol, refluxed for (10-12 hrs.).The reaction mixture was filtered, poured on ice water, dried and recrystallized the precipitate from ethanol-water to give crystals. Physical properties are listed in Table (3).

Synthesis of 5-bromo-3-[imino (acet amide)-N-4-p-bromo phenyloxazol-2yl]-2-oxo indole(17) and 5-bromo-3[(imino acetamide)-N-4-pbromophenylthiazol-2-yl]-2-oxo indole(18)[27]

The mixture compounds $(15,16)$ $(0.003 \mathrm{~mol})$ with $(0.83 \mathrm{~g}, 0.003 \mathrm{~mol}) p$ bromophenacyl bromide in $(10 \mathrm{ml})$ 
absolute ethanol was refluxed for (6-7 hrs.). Cooled, neutralized via solution of ammonium hydroxide. A solid product was filtered, washed with water and dried under vacuum. The product was recrystallized from ethanol. Physical properties and FTIR spectral data of these compounds are listed in Table (3).

Synthesis of 5-bromo-3-[imino(pphenyleneamine)]-2-oxo indole (19) [24]

A mixture of 5-Bromoisatin(Indole2,3-dione) (1g, $0.0044 \mathrm{~mol})$ with $p$ phenylenediamine $(0.48 \mathrm{~g}, 0.0044 \mathrm{~mol})$ in (10ml) DMF and 4-5 drops of glacial acetic acid, the mixture was refluxed for $12 \mathrm{hrs}$. The formed precipitate may be cooled off at room temperature before pouring into crushed ice, filtered with recrystalization from ethanol. Physical properties and FTIR spectral data of compound (19) are listed in Table (4).

Synthesis of 5-bromo-3-[imino( $p$ phenyl diazonium salt)]-2-oxo indole(20)[25]

A solution of compound (19) (0.6 g, $0.0019 \mathrm{~mol})$ in $(1.5 \mathrm{ml})$ concentration $\mathrm{HCl}$ was cooled to $(0-5)^{\circ} \mathrm{C}$. A Cooled solution of sodium nitrite $(0.13 \mathrm{~g}$, $0.0019 \mathrm{~mol})$ in $(5 \mathrm{ml})$ of water was added drop wise during 10min., then the reaction mixture was stirred for 30 min. Physical properties and FTIR spectral data of the product are listed in Table (4).

Synthesis of 5-bromo-3-[imino(pphenyl eneazido)]-2-oxo indole (21)[25]

An aqueous solution of sodium azid (1.5ml) $(0.3 \mathrm{~g}, 0.0017 \mathrm{~mol})$ was added drop wise to an aqueous solution of diazonium salt (20). The reaction mixture was stirred for 20 minutes to give an oily compound (21). Physical properties and FTIR spectral data are listed in Table (4).

Synthesis of 5-bromo-3-[imino( $p$ phenyl ene-4-acetyl-5-methyl-1H1,2,3-triazole)] -2-oxo indole(22)[25]
A cold solution of ( $3 \mathrm{ml}$.) sodium ethoxide, (0.15 g, $0.0015 \mathrm{~mol})$ acetyl acetone and $(0.5 \mathrm{~g}, 0.0015 \mathrm{~mol})$ compound (21) was gradually added. Refluxing the mixture for 3 hours. The resulting precipitate was separated and recrystallized by drying ether. Physical properties and FTIR spectral data of dry product are listed in Table (4).

Synthesis of 5-bromo-3-[imino( $p$ pheny lene-4-carboxylicacid-5methyl-1H-1,2,3 -triazole)]-2-oxo indole(23)[25]

Dissolving the mixture of compound (21) $(0.5 \mathrm{~g}, 0.0015 \mathrm{~mol})$ with ethyl acetoacetate $(0.195 \mathrm{~g}, 0,0015 \mathrm{~mol})$ in (5ml.) methanol was cooled to $0^{\circ} \mathrm{C}$. Sodium methoxide $(0.0015 \mathrm{~mol})$ in $(3 \mathrm{ml})$ methanol was added cautiously to the mixture and refluxed for 6 hours. The crude product was recrystallized from aceton. Physical properties and FTIR spectral data of dry product are listed in Table (4).

\section{Anti-bactrial activity test[28]}

The test was performed according to the disk diffusion method. Some of the synthesized compounds were tested against two strain -ve bacteria (Escherichia coli and pseudoman acruginosa) and two strain gram +ve (Bacilles and Staphylococcus aura). Whattman no.1, $5 \mathrm{~mm}$ diameter of filter paper disk were sterilized via autoclaving for $15 \mathrm{~min}$. at $121^{\circ} \mathrm{C}$. The sterile disks were impregnated with

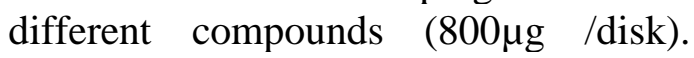
Agar plates were surface inoculated uniformly in $100^{\circ} \mu \mathrm{L}$ from both culture of tested microorganism. The impregnated disk was placed on the medium suitably spaced a part and the plates incubated at $5{ }^{\circ} \mathrm{C}$ for $1 \mathrm{hr}$. to permit good diffusion, then transferred to an incubator at $37^{\circ} \mathrm{C}$ for $24 \mathrm{hrs}$. . The inhibition zones caused by various compounds on the microorganisms were examined. 
The $2^{\text {nd }}$ National Conference of Chemistry

Table (1): Physical properties and FTIR spectral data $\mathrm{cm}^{-1}$ of compounds(1-7)

\begin{tabular}{|c|c|c|c|c|c|c|c|c|c|c|}
\hline \multirow{2}{*}{ Com.No. } & \multicolumn{4}{|c|}{ Physical Properties } & \multicolumn{6}{|c|}{ Major FTIR Absorption $\mathrm{cm}^{-1}$} \\
\hline & Structures & $\begin{array}{c}\text { M.P. } \\
\text { C }^{\circ}\end{array}$ & $\begin{array}{c}\text { Yield } \\
\%\end{array}$ & Color & $v(\mathrm{~N}-\mathrm{H})$ & $\begin{array}{l}v(\mathrm{C}-\mathrm{H}) \\
\text { arom. }\end{array}$ & $\begin{array}{c}v(\mathrm{C}=0) \\
\text { amide }\end{array}$ & $v(\mathrm{C}=\mathrm{N})$ & $v\left(\mathrm{SO}_{2}\right)$ & Others \\
\hline 1 & & $\begin{array}{l}225- \\
226\end{array}$ & 90 & orange & 3348 & $\begin{array}{l}3068 \\
3045\end{array}$ & 1706 & 1614 & $\begin{array}{c}\text { Sym. } \\
1164 \\
\text { Asym. } \\
1315\end{array}$ & - \\
\hline 2 & & $\begin{array}{r}184- \\
187\end{array}$ & 87 & orange & $\begin{array}{l}3218 \\
3201\end{array}$ & $\begin{array}{l}3074 \\
3062\end{array}$ & 1716 & 1612 & $\begin{array}{c}\text { Sym. } \\
1157 \\
\text { Asym. } \\
1375\end{array}$ & $\begin{array}{c}v(\mathrm{O}-\mathrm{H}) \\
3398\end{array}$ \\
\hline 3 & & $\begin{array}{c}176- \\
178\end{array}$ & 88 & orange & 3338 & $\begin{array}{l}3095 \\
3045\end{array}$ & 1703 & 1625 & $\begin{array}{c}\text { Sym. } \\
1163 \\
\text { Asym. } \\
1332\end{array}$ & $\begin{array}{c}v\left(\mathrm{NO}_{2}\right) \\
\text { Sym. } 1521 \\
\text { Asym. } 1388\end{array}$ \\
\hline 4 & & $\begin{array}{l}282- \\
284\end{array}$ & 87 & orange & 3271 & 3085 & 1720 & 1608 & $\begin{array}{c}\text { Sym. } \\
1197 \\
\text { Asym. } \\
1388\end{array}$ & $\begin{array}{c}v(\mathrm{C}-\mathrm{Cl}) \\
1091\end{array}$ \\
\hline 5 & & $\begin{array}{l}269- \\
271\end{array}$ & 84 & orange & $\begin{array}{l}3234 \\
3205\end{array}$ & 3049 & 1722 & 1610 & $\begin{array}{c}\text { Sym. } \\
1166 \\
\text { Asym. } \\
1389\end{array}$ & $\begin{array}{c}v P- \\
\text { Position } \\
821\end{array}$ \\
\hline 6 & & $\begin{array}{l}194- \\
196\end{array}$ & 85 & orange & $\begin{array}{l}3180 \\
3168\end{array}$ & 3055 & 1733 & 1610 & $\begin{array}{c}\text { Sym. } \\
1161 \\
\text { Asym. } \\
1305\end{array}$ & $\begin{array}{c}v(\mathrm{C}-\mathrm{Cl}) \\
1078 \\
v O- \\
\text { Position } \\
721\end{array}$ \\
\hline 7 & & $\begin{array}{l}295- \\
297\end{array}$ & 87 & orange & 3249 & 3039 & 1722 & 1610 & $\begin{array}{c}\text { Sym. } \\
1174 \\
\text { Asym. } \\
1305\end{array}$ & $\begin{array}{c}v(\mathrm{C}-\mathrm{H}) \\
\text { aliph. } 2991 \\
v P- \\
v P \\
\text { Position } \\
823\end{array}$ \\
\hline
\end{tabular}

Table (2): Physical properties and FTIR spectral data $\mathrm{cm}^{-1}$ of $\operatorname{compounds}(8-14)$

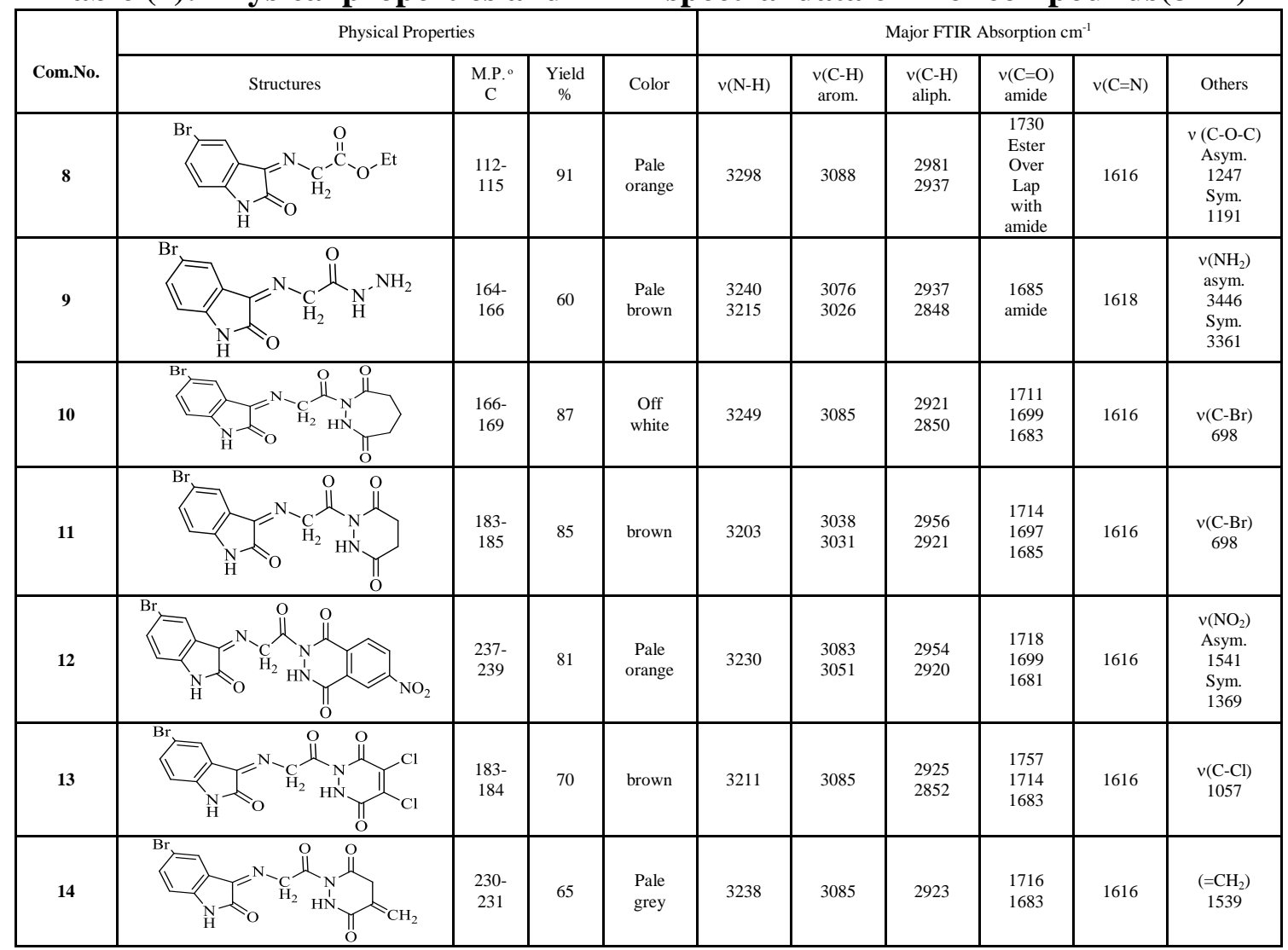


The $2^{\text {nd }}$ National Conference of Chemistry

Table (3): Physical properties and FTIR spectral data $\mathrm{cm}^{-1}$ of $\operatorname{compounds}(15-18)$

\begin{tabular}{|c|c|c|c|c|c|c|c|c|c|c|}
\hline \multirow{2}{*}{ Com.No. } & \multicolumn{4}{|c|}{ Physical Properties } & \multicolumn{6}{|c|}{ Major FTIR Absorption $\mathrm{cm}^{-1}$} \\
\hline & Structures & $\begin{array}{c}\text { M.P. 。 } \\
\text { C }\end{array}$ & $\underset{\%}{\text { Yield }}$ & Color & $v(\mathrm{~N}-\mathrm{H})$ & $\begin{array}{c}v(\mathrm{C}-\mathrm{H}) \\
\text { arom. }\end{array}$ & $\begin{array}{l}v(\mathrm{C}-\mathrm{H}) \\
\text { aliph. }\end{array}$ & $\begin{array}{c}v(\mathrm{C}=0) \\
\text { amide }\end{array}$ & $v(\mathrm{C}=\mathrm{N})$ & Others \\
\hline 15 & 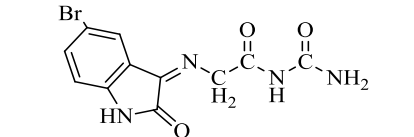 & $\begin{array}{l}148- \\
150\end{array}$ & 85 & $\begin{array}{l}\text { Pale } \\
\text { grey }\end{array}$ & 3245 & 3045 & $\begin{array}{l}2981 \\
2848\end{array}$ & $\begin{array}{l}1728 \\
1718\end{array}$ & 1616 & $\begin{array}{l}v\left(\mathrm{NH}_{2}\right) \\
\text { asym. } \\
3465 \\
\text { Sym. } \\
3340\end{array}$ \\
\hline 16 & & $\begin{array}{l}139- \\
141\end{array}$ & 80 & $\begin{array}{l}\text { Pale } \\
\text { gray }\end{array}$ & 3298 & 3031 & $\begin{array}{l}2908 \\
2852\end{array}$ & 1733 & 1618 & $\begin{array}{c}v\left(\mathrm{NH}_{2}\right) \\
\text { asym. } \\
3432 \\
\mathrm{Sym} . \\
3313 \\
v(\mathrm{C}=\mathrm{S}) \\
1242\end{array}$ \\
\hline 17 & $\prod^{\mathrm{PhBr}}$ & $\begin{array}{l}98- \\
100\end{array}$ & 84 & gray & 3259 & $\begin{array}{l}3056 \\
3033\end{array}$ & $\begin{array}{l}2906 \\
2854\end{array}$ & $\begin{array}{l}1731 \\
1695\end{array}$ & 1616 & $\begin{array}{c}v(\mathrm{C}-\mathrm{O}-\mathrm{C}) \\
1197,1070 \\
v P- \\
v P- \\
\text { Position } \\
808\end{array}$ \\
\hline 18 & $=\mathrm{H}_{\mathrm{H}_{2}} \mathrm{C}_{\mathrm{H}}^{\mathrm{O}} \mathrm{N}_{\mathrm{N}}^{\mathrm{C}} \prod^{\mathrm{PhBr}}$ & 98-99 & 80 & $\begin{array}{l}\text { Pale } \\
\text { gray }\end{array}$ & 3367 & $\begin{array}{l}3055 \\
3033\end{array}$ & $\begin{array}{l}2906 \\
2854\end{array}$ & $\begin{array}{l}1731 \\
1695\end{array}$ & 1616 & $\begin{array}{c}v(\mathrm{C}-\mathrm{S}-\mathrm{C}) \\
1290,1197 \\
v P- \\
\text { Position } \\
808\end{array}$ \\
\hline
\end{tabular}

Table 4 - Physical properties and FTIR spectral data $\mathrm{cm}^{-1}$ of $\operatorname{compounds}(19-23)$

\begin{tabular}{|c|c|c|c|c|c|c|c|c|c|}
\hline \multirow{2}{*}{$\begin{array}{l}\text { Com. } \\
\text { No. }\end{array}$} & \multicolumn{4}{|c|}{ Physical Properties } & \multicolumn{5}{|c|}{ Major FTIR Absorption $\mathrm{cm}^{-1}$} \\
\hline & Structures & $\begin{array}{l}\text { M.P. } \\
{ }^{\circ} \mathrm{C}\end{array}$ & $\begin{array}{c}\text { Yield } \\
\%\end{array}$ & Color & $v(\mathrm{~N}-\mathrm{H})$ & $\begin{array}{l}v(\mathrm{C}-\mathrm{H}) \\
\text { arom. }\end{array}$ & $\begin{array}{l}v(\mathrm{C}=0) \\
\text { amide }\end{array}$ & $v(\mathrm{C}=\mathrm{N})$ & Others \\
\hline 19 & & $\begin{array}{l}178- \\
180\end{array}$ & 93 & $\begin{array}{l}\text { Deep } \\
\text { red }\end{array}$ & 3228 & 3062 & 1730 & 1610 & $\begin{array}{c}v\left(\mathrm{NH}_{2}\right) \\
3413,3342 \\
v P \text {-Position. } \\
821\end{array}$ \\
\hline 20 & & oily & 79 & Brown & - & - & - & - & - \\
\hline 21 & & $\begin{array}{l}252- \\
254\end{array}$ & 80 & $\begin{array}{l}\text { Deep } \\
\text { Gray }\end{array}$ & 3226 & $\begin{array}{l}3068 \\
3045\end{array}$ & 1710 & 1616 & $\begin{array}{c}v \\
\mathrm{~N}=\mathrm{N}-\mathrm{N} \\
2123 \\
v P \text {-Position } \\
844 \\
844\end{array}$ \\
\hline 22 & & $\begin{array}{l}307- \\
310\end{array}$ & 65 & Brown & 3371 & 3039 & 1726 & 1614 & $\begin{array}{c}v(\mathrm{~N}=\mathrm{N}) 956 \\
v P \text {-Position } \\
823\end{array}$ \\
\hline 23 & & $\begin{array}{l}269- \\
270\end{array}$ & 63 & Brown & 3371 & 3045 & 1720 & 1614 & $\begin{array}{c}(\mathrm{O}-\mathrm{H}) \\
(3463- \\
2800) \text { brod } \\
v(\mathrm{~N}=\mathrm{N}) 977 \\
v P \text {-Position } \\
819\end{array}$ \\
\hline
\end{tabular}

\section{Results and Discussion:}

The synthetic sequences for synthesis of series of new 5-Bromoisatin linked to sulfonylamide, diazine, oxazole, thiazole and 1,2,3-triazole moieties as in Scheme(1). Compound (1) was synthesized by reaction of 5-bromoisatin with $p$-aminosulfonylchloride and dropes of glacial acetic acid in DMF to give schiff's bases compound(1). The mechanism involved two steps, the first step in condensation reaction involved nucleophilic addition while the second stepinclude eliminate water moleculeas to obtain Schiff base compounds $(1,8,19)$ by using glacial acetic acid as catalyst, the mechanism[24] as shown in Scheme(2). 


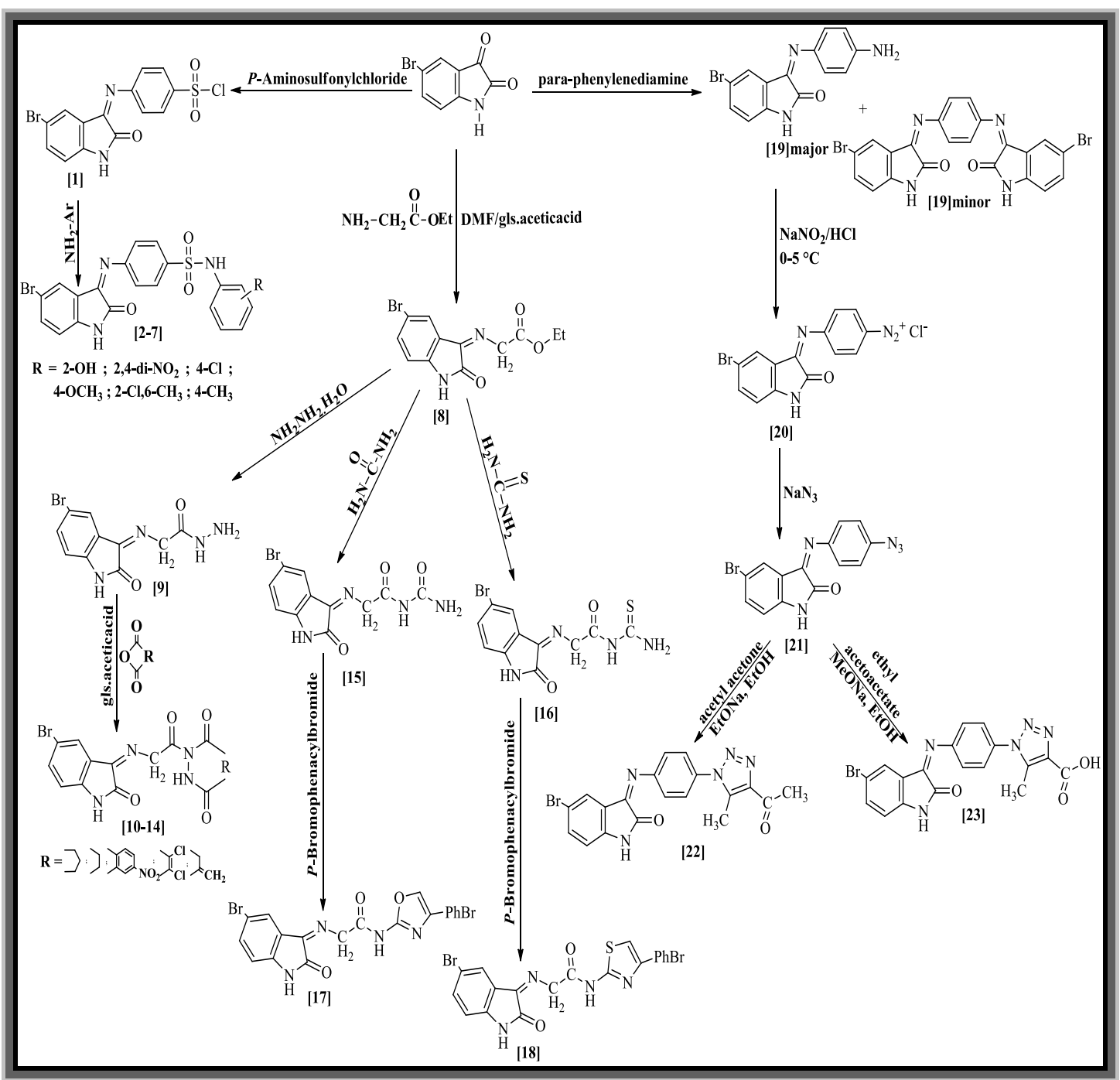

Scheme(1): Synthesis series of new sulfonylamide, diazine, oxazole, thiazole and 1,2,3-triazole derivatives of 5-Bromoisatin

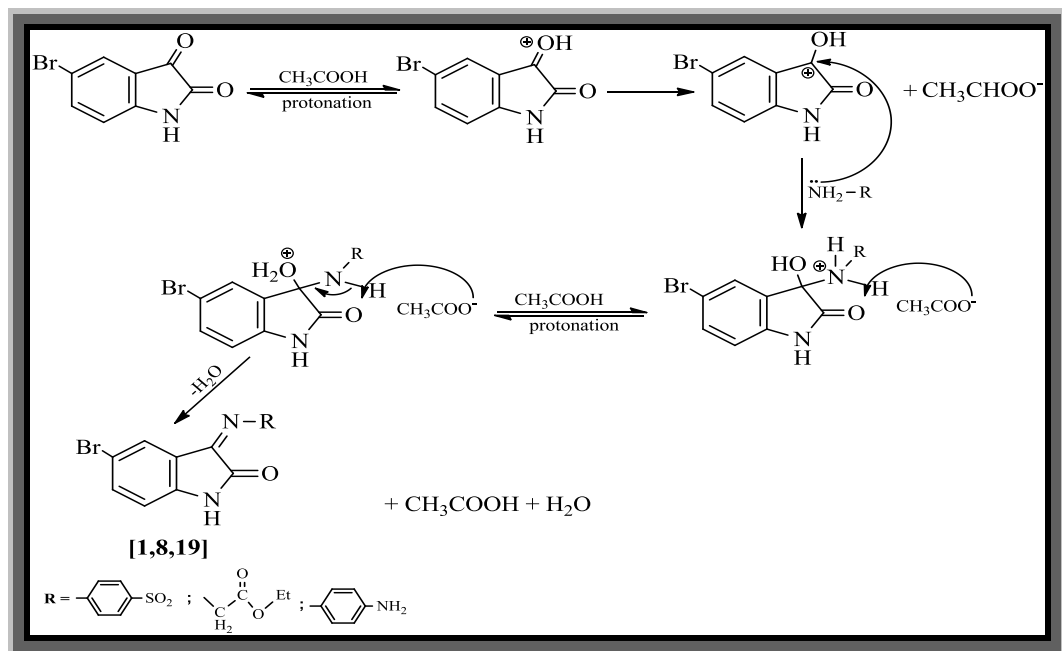

Scheme(2): Mechanism of synthesized compounds $[1,8,19]$ 
FTIR spectrum show absorption band $(3348) \mathrm{cm}^{-1}$ for $v(\mathrm{~N}-\mathrm{H})$; $(3068,3045)$ $\mathrm{cm}^{-1}$ for $v(\mathrm{C}-\mathrm{H})$ arom.; (1706) $\mathrm{cm}^{-1}$ for $v(\mathrm{C}=\mathrm{O})$ amide; $(1614) \mathrm{cm}^{-1}$ for $\mathrm{v}(\mathrm{C}=\mathrm{N})$; (1315) $\mathrm{cm}^{-1}$ for $v \mathrm{SO}_{2}$ asym.; 1164 for $\mathrm{vSO}_{2}$ sym. of compound(1) is listed in Table (1). Also sodium fusion test confirmed the presence of chlorine group[29]. Compound(2-7) was prepared by the reaction of compound(1) with different substituted primary aromatic amine in absolute ethanol. FTIR spectral showed absorption band (3398) $\mathrm{cm}^{-1}$ for $\mathrm{v}(\mathrm{O}-\mathrm{H})$; $(3218,3201) \mathrm{cm}^{-1}$ for $v(\mathrm{~N}-\mathrm{H})$; $(3074,3062) \mathrm{cm}^{-1}$ for $\mathrm{v}(\mathrm{C}-\mathrm{H})$ arom.; (1716) $\mathrm{cm}^{-1}$ for $v(\mathrm{C}=\mathrm{O})$ amide; ; (1612) $\mathrm{cm}^{-1}$ for $\mathrm{v}(\mathrm{C}=\mathrm{N}) ;(1375) \mathrm{cm}^{-1}$ for $\mathrm{vSO}_{2}$ asym.;1157 for $\mathrm{vSO}_{2}$ sym. of compound(2). And (3338) $\mathrm{cm}^{-1}$ for $v(\mathrm{~N}-$ $\mathrm{H})$; $(3095,3045) \mathrm{cm}^{-1}$ for $\mathrm{v}(\mathrm{C}-\mathrm{H})$ arom.; (1703) $\mathrm{cm}^{-1}$ for $v(\mathrm{C}=\mathrm{O})$ amide; $(1625)$ $\mathrm{cm}^{-1}$ for $\mathrm{v}(\mathrm{C}=\mathrm{N}) ;(1521) \mathrm{cm}^{-1}$ for $\mathrm{vNO}_{2}$ sym.; 1388 for $\mathrm{vNO}_{2}$ asym.; (1332) $\mathrm{cm}^{-1}$ for $\mathrm{vSO}_{2}$ asym.;1163 for $\mathrm{vSO}_{2}$ sym of compound(3). Besides (3217) $\mathrm{cm}^{-1}$ for v(N-H); (3085) $\mathrm{cm}^{-1}$ for v(C-H)arom.; (1720) $\mathrm{cm}^{-1}$ for $v(\mathrm{C}=\mathrm{O})$ amide; $(1608)$ $\mathrm{cm}^{-1}$ for $v(\mathrm{C}=\mathrm{N}) ;(1388) \mathrm{cm}^{-1}$ for $\mathrm{vSO}_{2}$ asym.; 1197 for $\mathrm{vSO}_{2}$ sym; (1091) $\mathrm{cm}^{-1}$ for $v(\mathrm{C}-\mathrm{Cl})$ of compound(4). $(3234,3205) \mathrm{cm}^{-1}$ for $v(\mathrm{~N}-\mathrm{H})$; (3049) $\mathrm{cm}^{-1}$ for $\mathrm{v}(\mathrm{C}-\mathrm{H})$ arom.; (1722) $\mathrm{cm}^{-1}$ for $v(\mathrm{C}=\mathrm{O})$ amide; $(1610) \mathrm{cm}^{-1}$ for $v(\mathrm{C}=\mathrm{N})$; (1389) $\mathrm{cm}^{-1}$ for $v \mathrm{SO}_{2}$ asym.;1166 for $\mathrm{vSO}_{2}$ sym; (821) $\mathrm{cm}^{-1} \mathrm{v} P$-position of compound(5). (3180,3168) $\mathrm{cm}^{-1}$ for $v(\mathrm{~N}-$ $\mathrm{H})$; (3055) $\mathrm{cm}^{-1}$ for v(C-H)arom.; (1733) $\mathrm{cm}^{-1}$ for $v(\mathrm{C}=\mathrm{O})$ amide; $(1610) \mathrm{cm}^{-1}$ for $v(\mathrm{C}=\mathrm{N}) ; \quad(1305) \quad \mathrm{cm}^{-1}$ for $\mathrm{vSO}_{2}$ asym.;1161 for $\mathrm{vSO}_{2} \mathrm{sym}$; (1078) $\mathrm{cm}^{-1}$ for $v(\mathrm{C}-\mathrm{Cl})$; $(721) \mathrm{cm}^{-1} \mathrm{v} O$-position of compound(6). And (3249) $\mathrm{cm}^{-1}$ for $v(\mathrm{~N}-$ $\mathrm{H})$; (3039) $\mathrm{cm}^{-1}$ for v(C-H)arom.; (2991) $\mathrm{cm}^{-1}$ for $v(\mathrm{C}-\mathrm{H})$ aliph.; (1722) $\mathrm{cm}^{-1}$ for $v(\mathrm{C}=\mathrm{O})$ amide; $(1610) \mathrm{cm}^{-1}$ for $v(\mathrm{C}=\mathrm{N}) ; \quad(1305) \mathrm{cm}^{-1}$ for $\mathrm{vSO}_{2}$ asym.;1174 for $\mathrm{vSO}_{2}$ sym (823) $\mathrm{cm}^{-1}$ vP-position of compound(7) All details of FTIR spectral data of compounds (2-
7) are listed in Table (1). ${ }^{1} \mathrm{H}-\mathrm{NMR}$ spectra data of compound(3) $\delta$ ppm in DMSO- $d_{6}$ solvent showed signal at $\delta=$ $(6.82-8.16) \mathrm{ppm}$ due to aromatic rings protons, singlet signal at $\delta=(8.35) \mathrm{ppm}$ due to $(\mathrm{S}-\mathrm{N}-\underline{\mathrm{H}})$ protons and singlet signal at $\delta=(8.78) \mathrm{ppm}$ due to $(\mathrm{N}-\underline{\mathrm{H}}$ indole ring) protons, as listed in Table(5) and shown in Figure(1). ${ }^{13} \mathrm{C}$-NMR spectrum data of compound(3) are listed in Table(6) and shown in Figure(2)

5-Bromoisatin react with ethyl glycinate to gave compound(8). FTIR spectrum of compound(8) showed the disappearance of $v(C=O)$ of ketone group with still appearance (3088) $\mathrm{cm}^{-1}$ for $v(\mathrm{C}-\mathrm{H})$ aromatic with appear new absorption band at $(2981,2937) \mathrm{cm}^{-1}$ for (C$\mathrm{H})$ aliph.; the absorption band at 1730 for $\mathrm{C}=\mathrm{O}$ (ester overlap with amide);1616 for $\mathrm{C}=\mathrm{N}$ imine and appearance of characteristic absorption bands at (1247asym., 1191sym) $\mathrm{cm}^{-1}$ for (C-OC). hydrazide derivative(9) synthesized by reaction of compound(8) with hydrazide hydrate $80 \%$. FTIR spectrum of synthesized compound(9) from the appearance of bands at (3446 and 3361) $\mathrm{cm}^{-1}$ which was assigned to the asymmetric and symmetric stretching bands of $\left(\mathrm{NH}_{2}\right)$ and $(\mathrm{NH})$ group's appearance of band at $(3240,3215) \mathrm{cm}^{-1}$. In addition to the disappearance of C-O$\mathrm{C}$ band at (1247asym., $1191 \mathrm{sym}) \mathrm{cm}^{-1}$ of compound(8). Diazine derivatives (10-14) were synthesized by the reaction of hydrazide derivative(9) with (Glutaric anhydride, succinic anhydride,4nitrophthalic anhydride ,2,3 dichloro malic anhydride and itaconic anhydride) respectively. The FTIR spectra of compounds (10-14) show the disappearance of the two bands of ($\mathrm{NH}_{2}$ ) group of hydrazide derivative (9). FTIR spectral data of compounds (1014) appearance of a band due to $(-\mathrm{NH})$ group at the range $(3249-3203) \mathrm{cm}^{-1}$. Two carbonyl groups of compounds(1014) appeared at (1757-1711) $\mathrm{cm}^{-1}$ for cyclic carbonyl and at (1699-1681) $\mathrm{cm}^{-1}$ 
for the amide carbonyl. All details of FTIR Spectral data of compounds (8-14) are listed in Table(2). ${ }^{1} \mathrm{H}-\mathrm{NMR}$ spectrum for compound(11) showed triplet signal at $\delta=(3.32) \mathrm{ppm}$ due to $\left(-\mathrm{C}_{2}{ }_{2}-\underline{\mathrm{C}}_{2}-\right)$ protons, singlet signal at $\delta=(4.64) \mathrm{ppm}$ due to $\left(=\mathrm{N}-\underline{C}_{2} \underline{2}^{-}\right)$protons, signal at $\delta=(6.74-7.67) \mathrm{ppm}$ due to aromatic rings protons, singlet signal at $\delta=(8.12) \mathrm{ppm}$ due to $(\mathrm{N}-\mathrm{N}-\underline{\mathrm{H}})$ protons, and singlet signal at $\delta=(9.82) \mathrm{ppm}$ due to $(\mathrm{N}-\underline{\mathrm{H}}$ indole ring) protons as listed in Table (5) and shown in Figure(3). ${ }^{13} \mathrm{C}-\mathrm{NMR}$ spectral data are listed in Table(6) and shown in Figure(4).

The compound(8) was converted to urea(15) and thiourea(16) derivatives via reaction with (urea and thiourea) respectively. FTIR spectral date showing the absorption at $\left(3465 \mathrm{~cm}^{-1}\right)$ asym. (3340 cm-1) sym. for $\mathrm{NH}_{2},(3245$ $\left.\mathrm{cm}^{-1}\right)$ for $\mathrm{NH},\left(1728,1718 \mathrm{~cm}^{-1}\right)$ for $\mathrm{C}=\mathrm{O}$ amide, $\quad\left(1616 \mathrm{~cm}^{-1}\right)$ for $\mathrm{C}=\mathrm{N}$ of compound(15). (3432 $\left.\mathrm{cm}^{-1}\right)$ asym. $\left(3313 \mathrm{~cm}^{-1}\right)$ sym. for $\mathrm{NH}_{2},\left(3298 \mathrm{~cm}^{-1}\right)$ for $\mathrm{NH},\left(1733 \mathrm{~cm}^{-1}\right)$ for $\mathrm{C}=\mathrm{O}$ amide, $\left(1618 \mathrm{~cm}^{-1}\right)$ for $\mathrm{C}=\mathrm{N},\left(1242 \mathrm{~cm}^{-1}\right)$ for $\mathrm{C}=\mathrm{S}$, of compound(16). FTIR spectra of these compounds that shows results are listed in Table(3). Cyclization of (urea and thiourea)derivatives compound $(15,16)$ by $p$-bromophenacylbromide to obtain oxazole and thiazole derivatives. FTIR spectral date showing the absorption at $\left(3259 \mathrm{~cm}^{-1}\right)$ for $\mathrm{NH}$, $\left(1731,1695 \mathrm{~cm}^{-1}\right)$ for $\mathrm{C}=\mathrm{O}$ amide, $(1616$ $\left.\mathrm{cm}^{-1}\right)$ for $\mathrm{C}=\mathrm{N}$ amide, $(1197$ asym.,1070sym. $\mathrm{cm}^{-1}$ ) for C-O-C, (808 $\mathrm{cm}^{-1}$ ) for $P$-position of compound(17). $\left(3367 \mathrm{~cm}^{-1}\right)$ for $\mathrm{NH},\left(1731,1695 \mathrm{~cm}^{-1}\right)$ for $\mathrm{C}=\mathrm{O}$ amide, $\left(1616 \mathrm{~cm}^{-1}\right)$ for $\mathrm{C}=\mathrm{N}$ amide, (1290 asym.,1197sym. $\mathrm{cm}^{-1}$ ) for C-S-C, $\left(808 \mathrm{~cm}^{-1}\right)$ for $P$-position of compound(18). FTIR spectra of these compounds that shows results are listed in Table(3). ${ }^{1} \mathrm{H}-\mathrm{NMR}$ spectrum of compound(17) showed singlet signal at $\delta=(4.75) \mathrm{ppm}$ due to $\left(=\mathrm{N}-\underline{\mathrm{C}}_{2}-\right)$ protons, singlet signal at $\delta=(7.53) \mathrm{ppm}$ due to oxazole ring proton, signal at $\delta=(7.71-$
8.08) ppm due to aromatic rings protons, singlet signal at $\delta=(9.30) \mathrm{ppm}$ due to $(\mathrm{N}-$ $\underline{\mathrm{H}}$ oxazole ring)protons and singlet signal at $\delta=(9.45) \mathrm{ppm}$ due to $(\mathrm{N}-\underline{\mathrm{H}}$ indole ring) as shown in $\operatorname{Table}(5) .{ }^{13} \mathrm{C}$ NMR spectral data are listed in Table(6).

Synthesis of 1,2,3-triazoles compounds $(22,23)$ via condensation 5bromoisatin with $p$-phenylenediamine in ethanol as a solvent to give the compound(19). Which the diazotation of compound(19) to obtained diazonium chloride(20)[30] . The 1,2,3-triazoles are very important organic compounds having wide spectrum of biological activities $^{[31]}$. The reaction must be carried out in low temperature between $(0-5)^{\circ} \mathrm{C}$ because the high temperature decomposition of diazonium salt(20), the obtained diazonium chloride(20) was treated with calculated amount of sodium azide to afford compound(21). FTIR spectrum of compounds(19-23) showed the absorption at $v \mathrm{~cm}^{-1}(2123$ for $\mathrm{N}=\mathrm{N}-\mathrm{N}$ group). The azide derivative(21) was converted to compounds(22) and (23) via the reaction with acetylacetone and ethylacetoacetate respectively. The $2+3$ cycloaddition implies a reaction between 1,3-dipole 5bromo-3-[imino( $p$-phenyleneazido)]-2oxo indole and 1,3-diketone or $\beta$-keto ester compounds called dipolarophile [acetylactone and ethylacetoacetate] in basic solution [EtOH+EtONa]. FTIR spectral showed the disappearance of the azid group $\left(\mathrm{N}_{3}\right)$ band in the starting material[21] at $\left(2123 \mathrm{~cm}^{-1}\right)$ which is a good indication for successful condensation. The spectrum also shows absorption bands at $\left(1726 \mathrm{~cm}^{-1}\right.$ for $v$ $\mathrm{C}=\mathrm{O}$ amide; $1614 \mathrm{~cm}^{-1}$ for $\nu \mathrm{C}=\mathrm{N}$ imine; $956 \mathrm{~cm}^{-1}$ for $\left.v \mathrm{~N}=\mathrm{N}\right)$. For compound(22); $\left[1720 \mathrm{~cm}^{-1}\right.$ for $v \mathrm{C}=\mathrm{O}$ amide; $1614 \mathrm{~cm}^{-1}$ for $v \mathrm{C}=\mathrm{N}$ imine; $977 \mathrm{~cm}^{-1}$ for $v \mathrm{~N}=\mathrm{N}$ in addition appearance abrod band (34632800) $\mathrm{cm}^{-1}$ for $\left.\mathrm{vO}=\mathrm{C}-\mathrm{OH}\right]$ for compound(23). All details of FTIR Spectral data of compounds(19-23) are 
The $2^{\text {nd }}$ National Conference of Chemistry

listed in Table(4). ${ }^{1} \mathrm{H}-\mathrm{NMR}$ spectrum of compound (22) $\delta p p m$ in DMSO- $d_{6}$ solvent showed singlet signal at $\delta=(2.49) \mathrm{ppm}$ due to $\left(\mathrm{O}=\mathrm{C}-\mathrm{C}_{3}\right)$ protons, singlet signal at $\delta=(3.31) \mathrm{ppm}$ due to $\left(\mathrm{CH}_{3}\right)$ protons, signal at $\delta=(6.77$ - 7.76)ppm due to aromatic rings protons and singlet signal at $\delta=(8.21) \mathrm{ppm}$ due to (N-ㅍ indole ring) proton, as listed in Table(5) and shown in Figure (5). ${ }^{13} \mathrm{C}$ NMR spectral data of compound(22) are listed in Table(6) and shown Figure(6).

Table (5): ${ }^{1} \mathrm{H}-\mathrm{NMR}$ spectral data ( $\left.\delta \mathrm{ppm}\right)$ for selected compounds

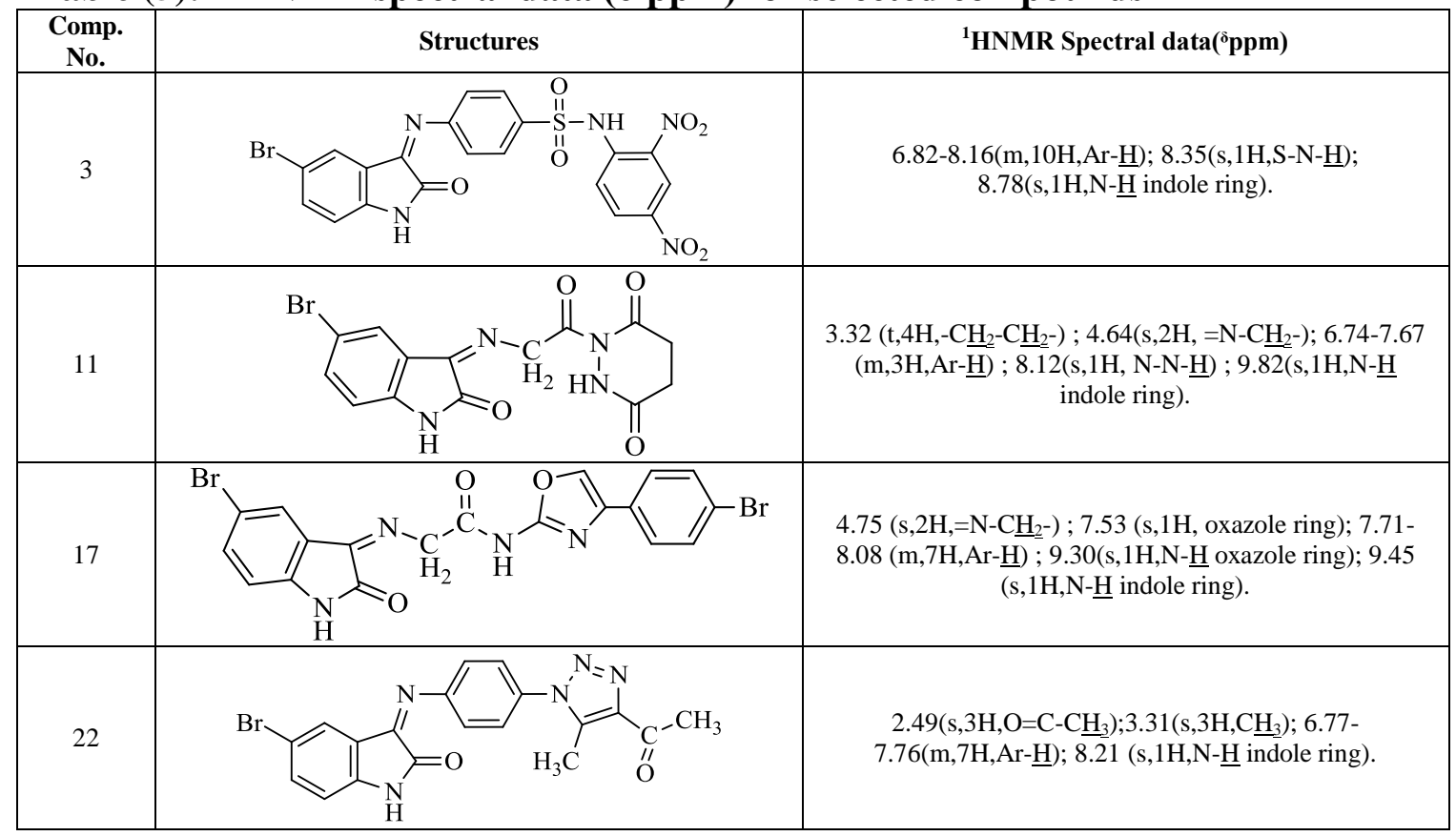

Table $(6):{ }^{13} \mathrm{CNMR}$ spectral data $(\delta \mathrm{ppm})$ for selected compounds

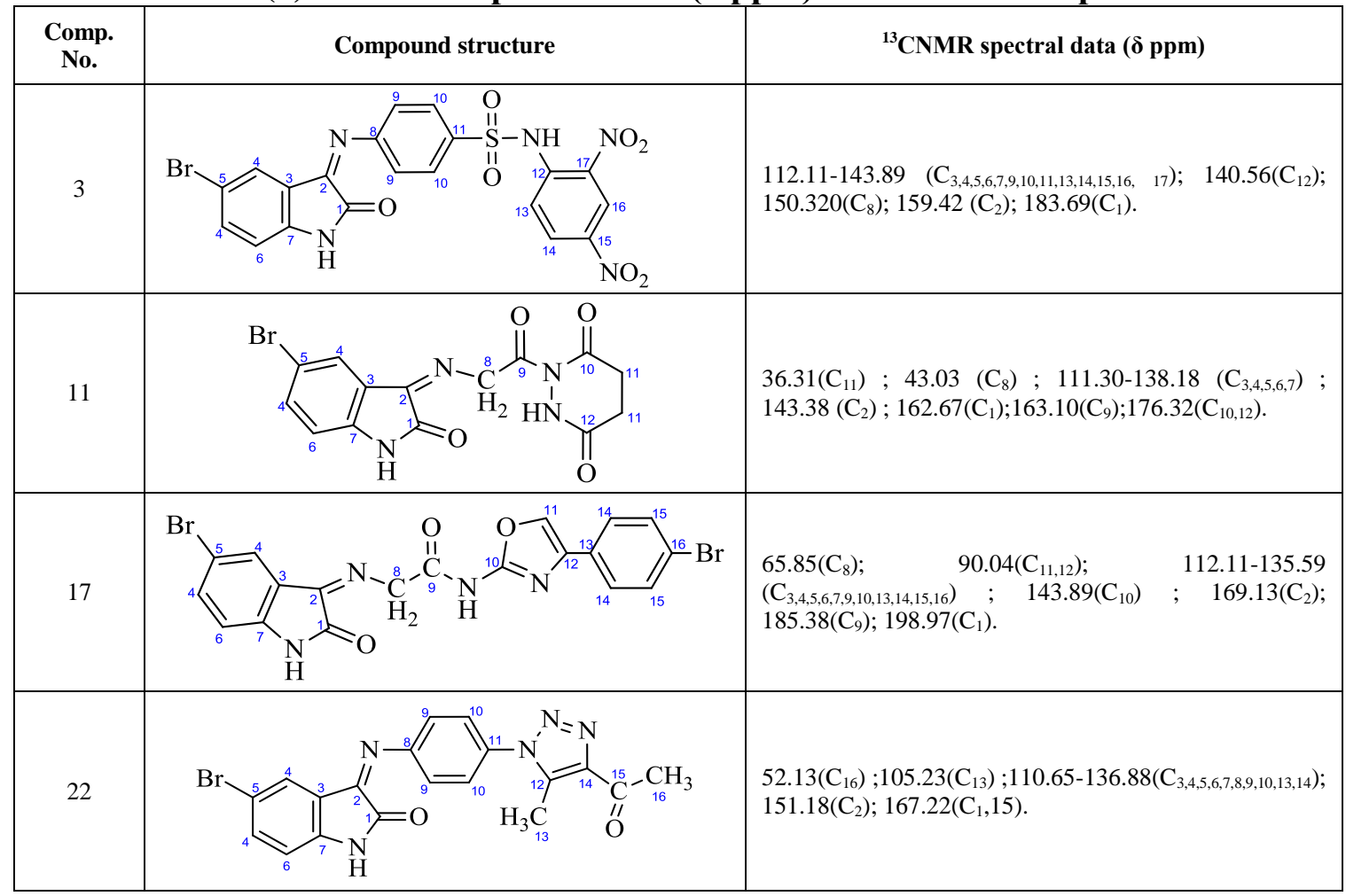




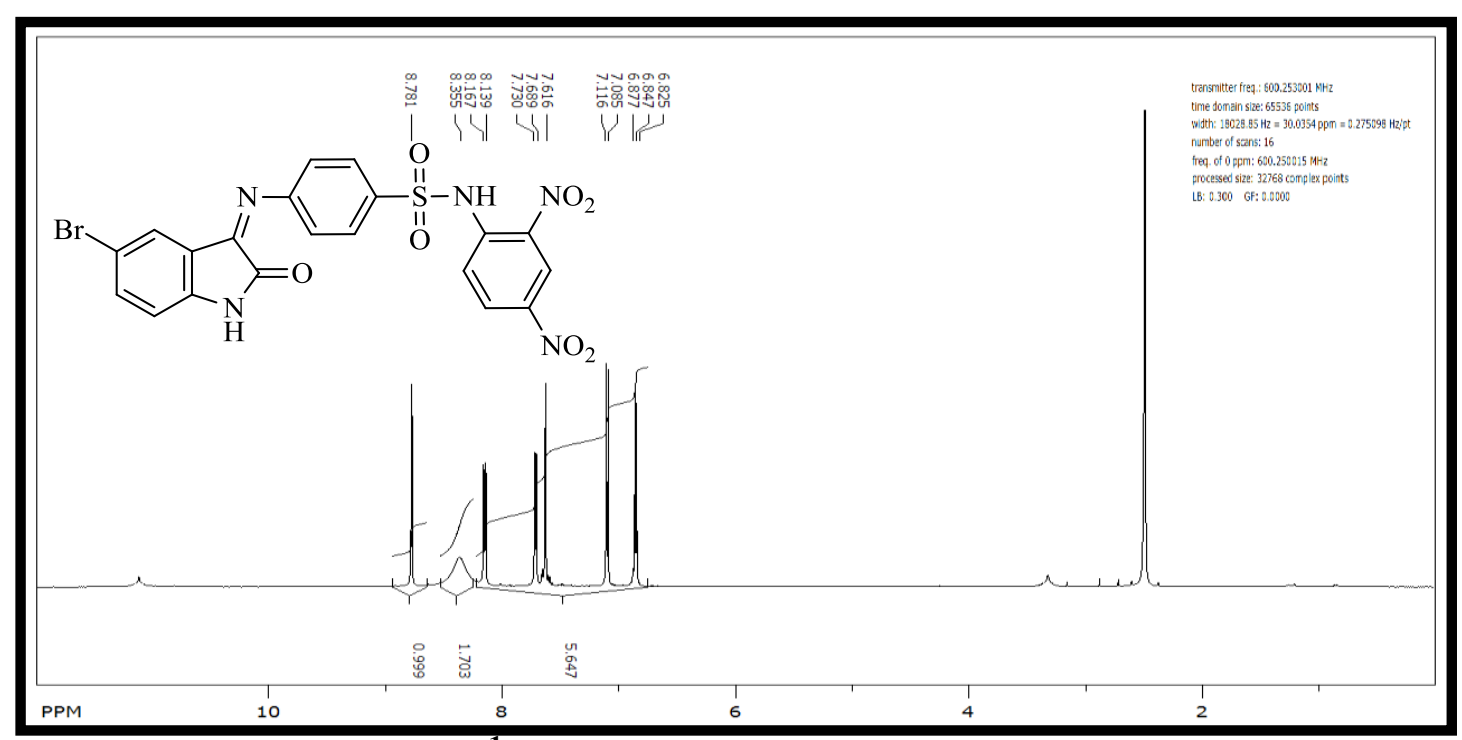

Fig. (1): ${ }^{1}$ H-NMR spectrum for compound(3)

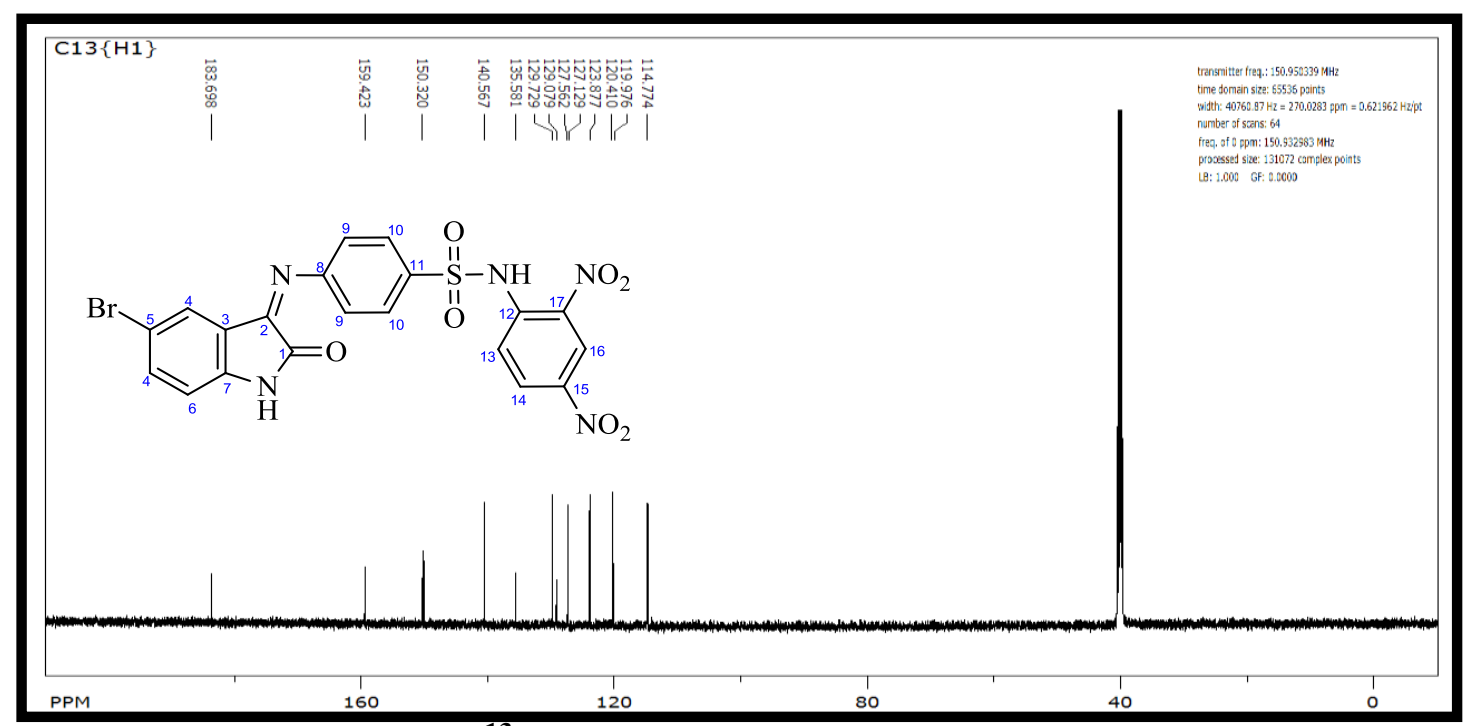

Fig. (2): ${ }^{13}$ C-NMR spectrum for compound(3)

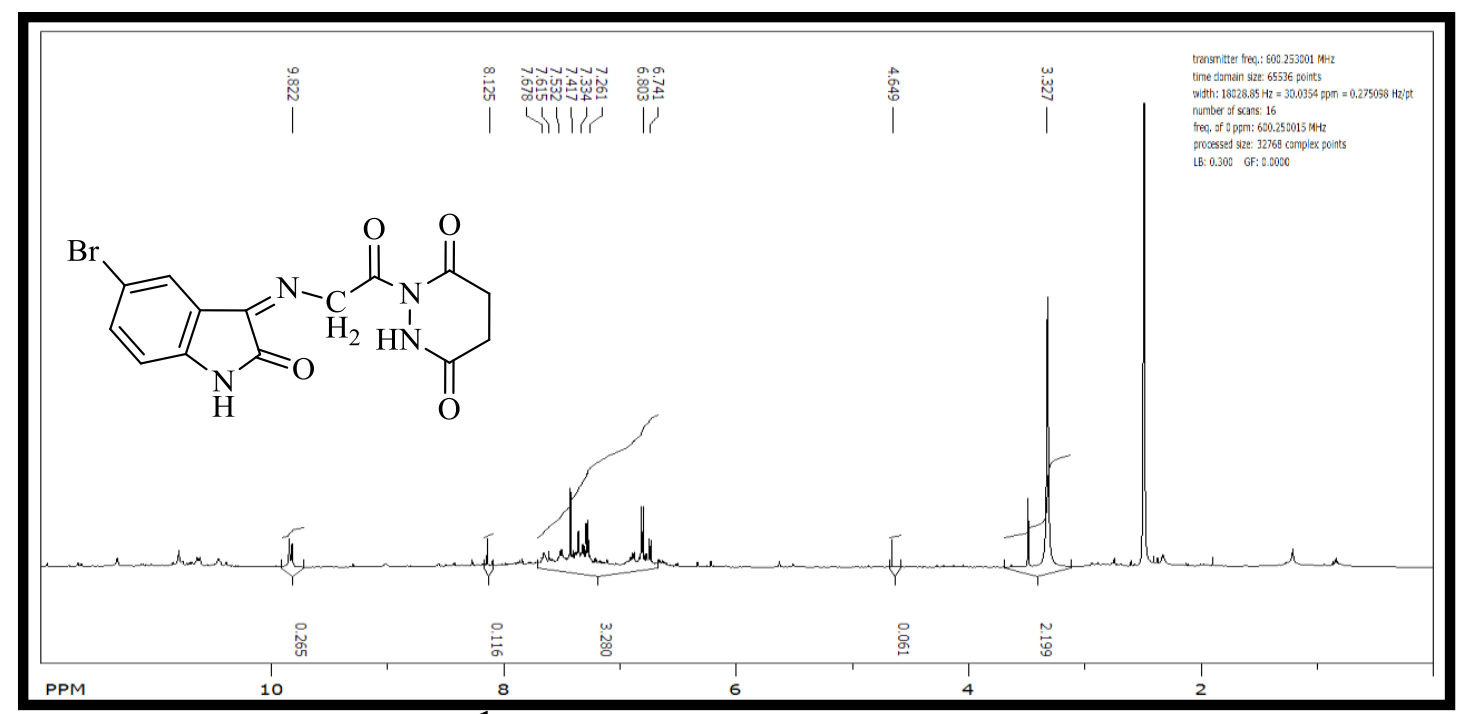

Fig. (3): ${ }^{1}$ H-NMR spectrum for compound(11) 


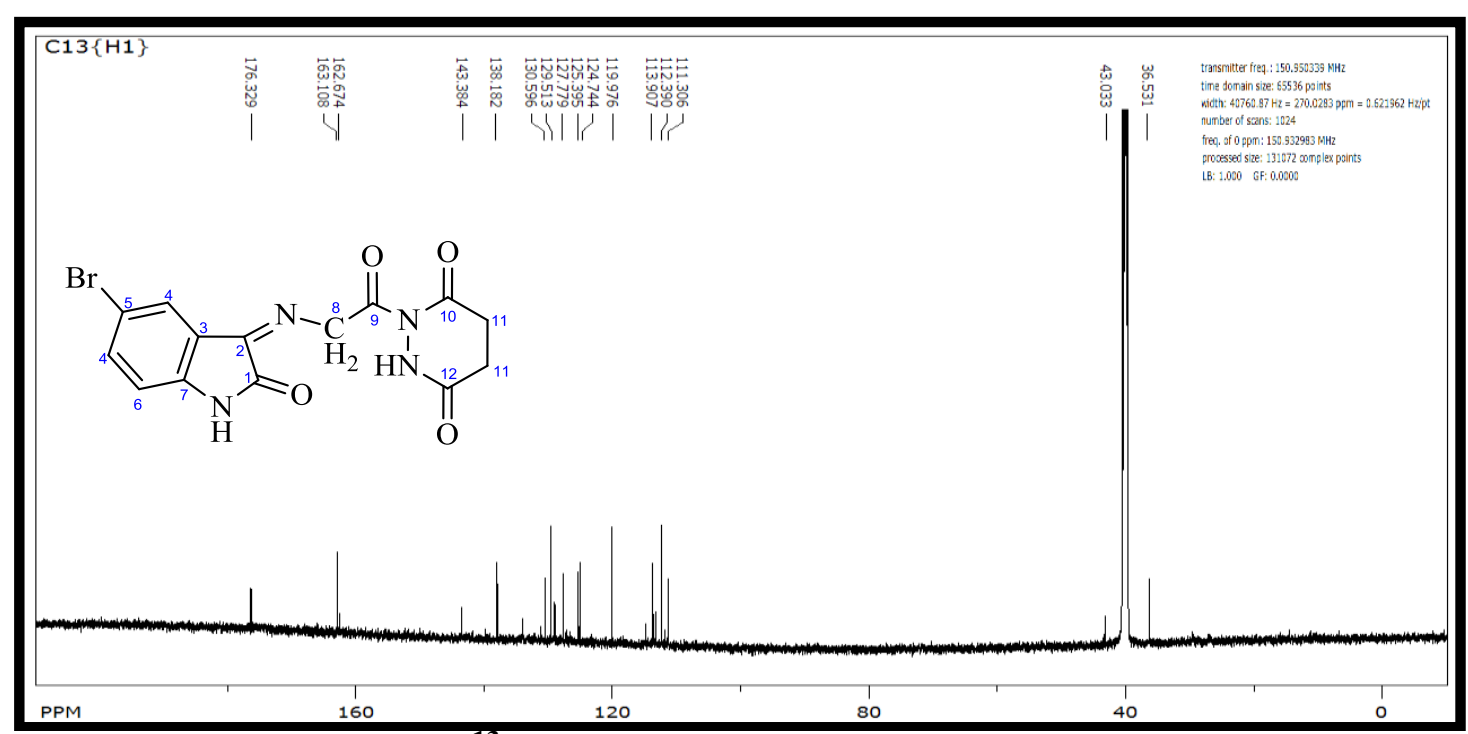

Fig. (4): ${ }^{13}$ C-NMR spectrum for compound(11)

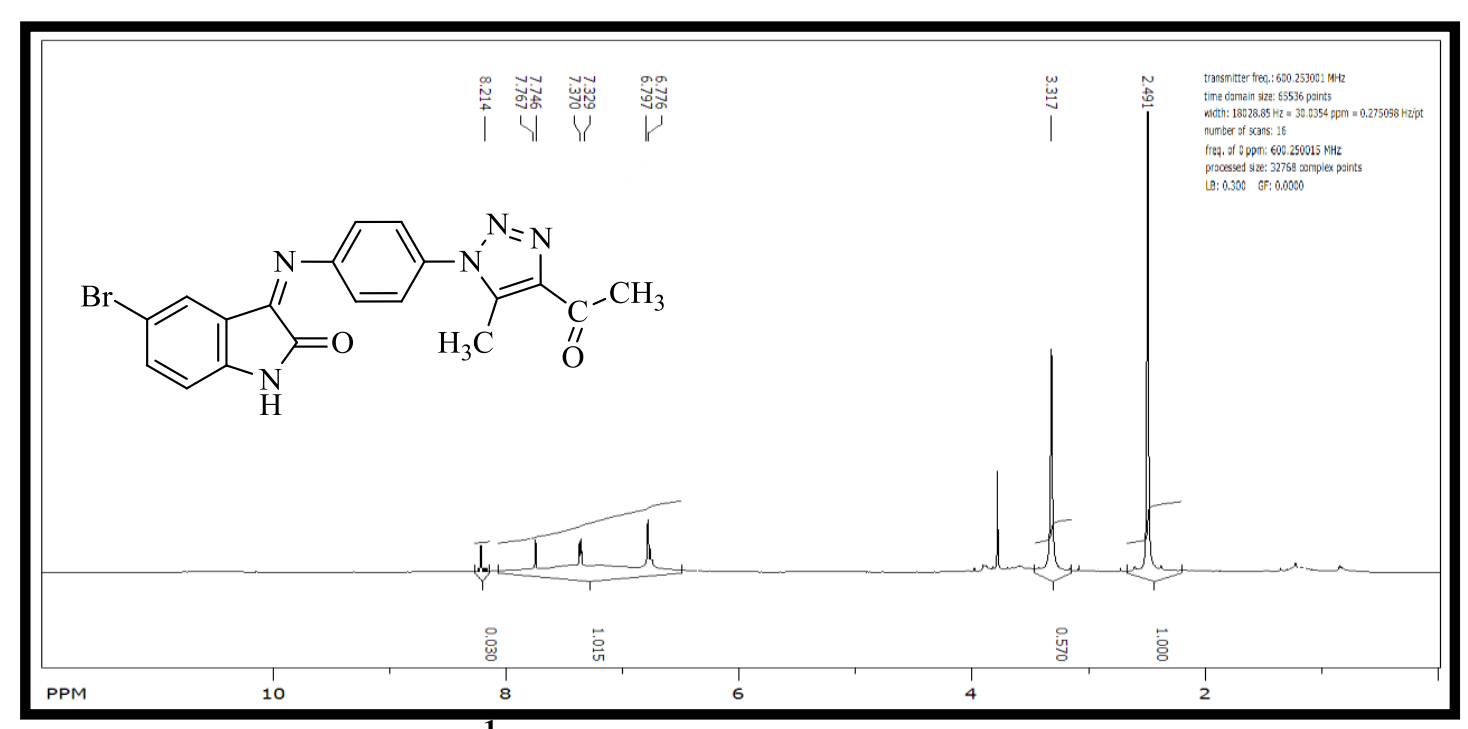

Fig. (5): ${ }^{1}$ H-NMR spectrum for compound(22)

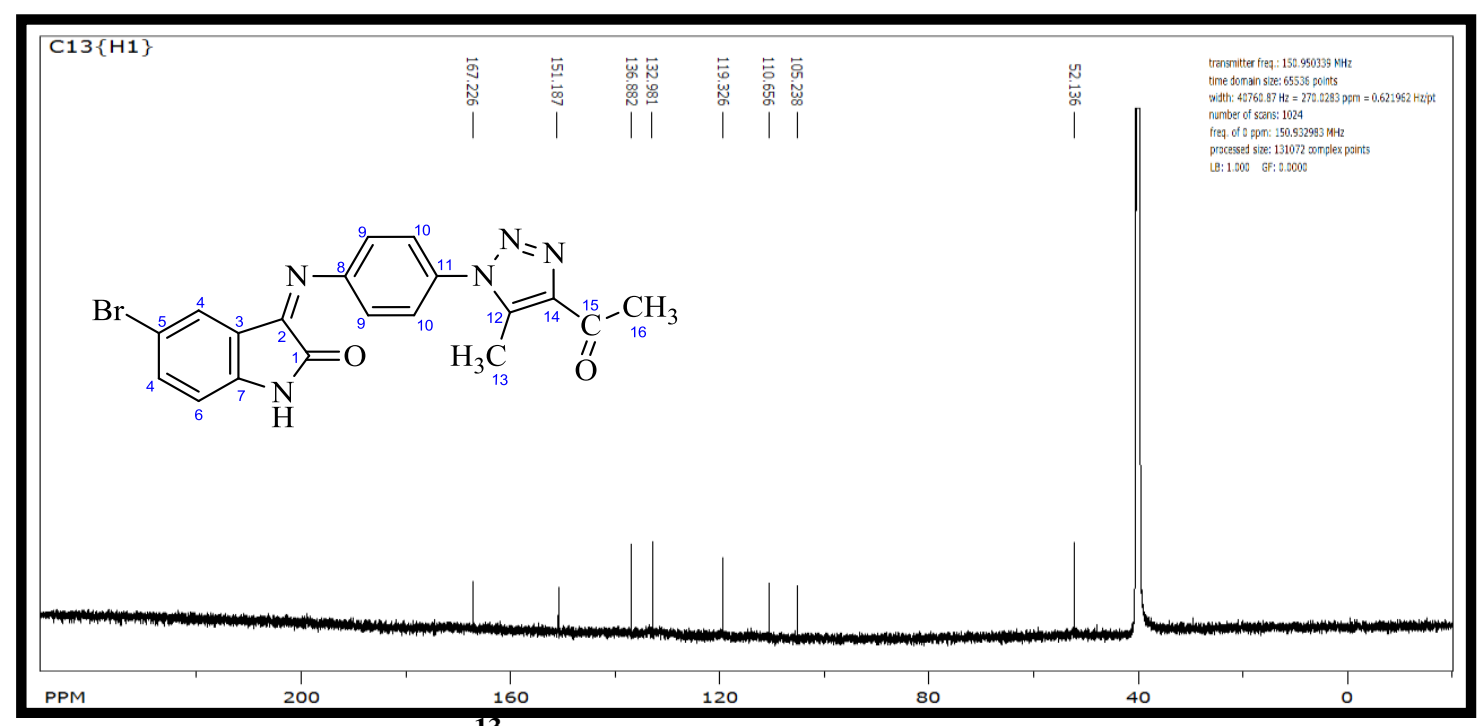

Fig. (6): ${ }^{13}$ C-NMR spectrum for compound(22) 


\section{Anti-bacterial Activity Study:}

The results of antibacterial activity are listed in Table(7). The results referred that all synthetic compounds possess moderate activity against certain types of bacteria. Compound $(2,19)$ possesses moderate activity against Staphylococcus aureus. Compounds (8) possess a moderate activity against Bacillies subtilus while compounds $(1,2,9,15,19,22,23)$ possess a moderate activity against for same bacteria. Escherichia coli showed weak activity by compounds $(1,8,9,18)$ and showed moderate activity for compound(15). compound(1,2,23) possesses a good activity against Pseudomonas aeruginosa with a moderate activity for compound $(8,9,11,19,22)$.

Table (7): Anti-bacterial activity of the tested prepared compounds

\begin{tabular}{|c|c|c|c|c|}
\hline $\begin{array}{c}\text { Comp. } \\
\text { No. }\end{array}$ & $\begin{array}{c}\text { Staphylococcus } \\
\text { aureus }\end{array}$ & $\begin{array}{c}\text { Bacillies } \\
\text { subtilus }\end{array}$ & $\begin{array}{c}\text { Escherichia } \\
\text { coli }\end{array}$ & $\begin{array}{c}\text { Pseudomones } \\
\text { aerginosa }\end{array}$ \\
\hline $\mathbf{1}$ & 6 & 5 & 2 & 12 \\
\hline $\mathbf{2}$ & 7 & 5 & - & 11 \\
\hline $\mathbf{8}$ & 5 & 7 & 3 & 8 \\
\hline $\mathbf{9}$ & 4 & 6 & 4 & 10 \\
\hline $\mathbf{1 1}$ & 2 & - & - & 8 \\
\hline $\mathbf{1 5}$ & 5 & 2 & 8 & - \\
\hline $\mathbf{1 8}$ & - & - & 6 & - \\
\hline $\mathbf{1 9}$ & 8 & 2 & - & 10 \\
\hline $\mathbf{2 2}$ & 5 & 3 & - & 10 \\
\hline $\mathbf{2 3}$ & 6 & 2 & - & 12 \\
\hline
\end{tabular}

Solvent: DMSO ; [C]: $800 \mu \mathrm{g} / \mathrm{ml}$.

Zone of inhibition: (-) no inhibition zone; (3-6) weak; (7-10) moderate; (11$15)$ strong.

\section{Conclusion:}

The present research involves the synthesis of sulfonylamide, diazine, oxazole, thiazole and 1,2,3-triazole derivatives of 5-Bromoisatin to explore their antibacterial activity. Exhibited highest antibacterial activity for staphylococcus aureus compound(19), Bacilliessubtilus compound(8), Escherichia coli compound(15) and Pseudomonas aeruginosa compound $(1,23)$. Hence, it is conculuded that there is in ample scope for further study in developing these as good lead compounds for the treatment of bacterial strain as well as fungal strain.

\section{References:}

[1] Satish, K. and Gajanans, S. 2015. New strategy for the green synthesis and biological evolution for the synthesis of 2-oxospiro[indoline-3,2'thiazolidine]-3'-yl)benzoic acid derivative. RJPBCS, 6(2):817-827.

[2] Reena, D. and Amit, C. 2015. Design, Synthesis and Biological Activity of Isatin Derivatives. Chem. Sci. Trans., 4(1):208-212.

[3] Ratnamala, P. 2014. Synthesis and Characterisation of 1H-indole-2,3dione and its Novel Derivatives. AJBPAD, 4(1):129-134.

[4] Pamita, A.; Shilpa, D.; Manu, V. and Ritu, B. 2015. Comparative in silico and in vitro Study of N-(1-Methyl-2Oxo-2-N-Methyl Anilino-Ethyl) Benzene Sulfonamide and Its Analogues as an Anticancer Agent. I.Scholarly and Sci.R.I., 9(3):409412.

[5] Venkata, S.; Venkata, K.; Subramanyam, C.; Adam, S. and Naga, R. 2013. Synthesis of carbamate and sulfonamide derivatives of amlodipine and their antimicrobial activity. Der Pharm. Sinica, 4(1):10-16.

[6] Neha, B.; Basabi, R.; Sibanth, M and Mahendra, N. 2015. Synthesis and antibacterial evaluation of novel sulfonamide based [1,2,3]-triazoles. I.J.Chem., 54:650-655.

[7] Sutanun, D.; Apilak, W.; Ratchanok, P.; Thummaruk, S.; Supaluk, P.; Somsak, R. and Virapong, P. 2011. Investigation on Biological Activities of Anthranilic Acid sulfonamide analogs. Excli J., 10:155-161.

[8] Iryna, S.; Helen, T. and Vitaliy, A. 2014. Synthesis and Neurotrotropic Activity of Novel Sulfolane- 
containing Cage Sulfonamides. Eur. Chem. Bull., 3(6):543-547.

[9] Muddassar, S.; Ammar, B.; Sohail, A. and Naveed,A. 2013. Synthesis and Biological Evaluation of Hydrazide based Sulfonamides. J.Sci. \& In.R., 2(3):627-633.

[10] Aneta, K.; Iwona, F.; Justyna, A. and Danuta. B. 2014. Biological activity and synthesis of sulfonamide derivatives: a brief review. CHEMIK, 68(7):620-628.

[11] Hatem, E.; Mohamed, E. and Magdy, K. 2014. Synthesis of Some Novel Antibacterial Sulfonamide Reactive Dyes. Life Sci. J., 11(11):138-142.

[12] Ajeet, A. and Arvind, K. 2015. Recent Advances in Development of Sulfonamide Derivatives and Their Pharmacological Effects- A Review. A.J.Pharm. Sci., 3(1):18-24.

[13] El-Ansary, A. ; Kamal, A. and AlGhorafi, M. 2013. Design and Synthesis of Some Thieno [2,3c]pyridazine Derivatives of Expected An-ticancerActivity. Med.Chem. Res., 22:2589-2601.

[14] Ahmed, S.; Ahmed, A.; Mohammed, H. and Mokhtar, A. 2014. Synthesis and antibacterial activity of some novel thieno[2,3c]pyridazines using 3-amino-5phenyl-2- ethoxycarbonylthieno[2,3c]pyridazine as a starting material. Ara.J.Chem., 7:775-780.

[15] Jayaraman, S.; Nagappan, R.; Chowdappa, S.; Konappa, N. and Krishnamurthy, S. 2014. Antimicrobial Activities of Novel 3Substituted [1,2,4] Triazolo[4,3b]pyridazines. Journal of the Korean Chemical Society, 58(4):377-380.

[16] Jian, W.; Baoan, S.; Hongjun, C.; Pinaki, B. and Deyu, H. 2009. Synthesis and Antifungal Activity of 5-Chloro-6-Phenylpyridazin-3(2H)one Derivatives. Molecules, 14:36763687.
[17] Yassin, F. 2010. Novel pyrazolyl pyridazine derivatives likely to possess anti inflammatory activity. J. Microbiol. Antimicrob., 2(7):93-99.

[18] Naif, O.; Saleh, A.; Ahmed, A. and Mohamed, A. 2013. Pharmacological activities evaluation of some new pyrazolo-pyrimidino-pyridazine derivatives. Afr. J. Pharm. Pharmacol, 7(9):517-523.

[19] Saleh, A.; Bahshwan, A. and Ahmed, A. 2010. Synthesis and Pharmacological Activities of Some Thieno Pyridazine Derivatives Using 5-Amino-4-Ethoxycarbonyl

Phenanthro [9,10-e] Theino[2,3-c] Pyridazine as a Starting Material. J. A. Sci., 6(10):85-92.

[20] Bushra, A.; Manal, A.; Abdulkareem, A.; Abdullah, M. and Baseer, M. 2014. Synthesis and Spectroscopic Studies of Some New Oxazole Derivatives Dyes. Int. J. Pharm. Sci., 26(2):162-166.

[21] Hamid, B.; Reza, A. and Hadi, M. 2015. Novel one-pot process for the synthesis of ethyl 2-imino-4- methyl-2,3-dihydrothiazole-5-

carboxylates. J. Serb. Chem. Soc., 80(0):1-8.

[22] Satyanarayana, R.; Srinivasa, R.; Chowdoji, R. and Subha .2015. Synthesis of some 1,2,3-Triazole Derivatives of indole with potential Antimicrobial Activity. W.J.Pharm. and Pharm. Sci., 4(3):1084-1090.

[23] Mohammad, I.; Mohsin, K.; Nikhat, M. and Mohammad, A. 2014. Synthesis of N-2-aryl-substituted1,2,3-triazole Derivatives as Novel Inhibitors of Entamoeba histolytica. OJOC, 2(2):21-28.

[24] Al-Majidi, S. M. and Lawand, H. 2015. Synthesis and antimicrobial evaluation activity of some new substituted spiro-thiazolidine, Imidazolinone and azetidine derivatives of 5-Bromo Isatin. J. Zankoi Sulaimani, 17(1):49-59. 
The $2^{\text {nd }}$ National Conference of Chemistry

[25] Redhab, A. and Al-Majidi, S.M.. 2014. Synthesis, Characterization and Evaluation of Antimicrobial Activity for New Heterocyclic Derivatives Containing Pentagonal, Hexagonal Rings. Iraqi J. Sci., 55(4):1694-1707.

[26] Mohammed, G. and Al-Majidi, S. M. 2014. Synthesis, Characterization and Evaluation Antimicrobial Activity of Some New substituted 2Mercapto-3-Phenyl-4(3H)-

Quinazolinone. Iraqi J.Sci., 55(2):582-593.

[27] Al-Majidi, S. M. and Redhab, A. 2015. Synthesis and evaluation antimicrobial activity of some new Ssubstituted Quinazolinone containing pentagonal, hexagonal heterocyclic ring. J. Zankoi Sulaimani, 17(1):3348.
[28] Anesini, C. and Perez, C. 1993. Screening of plants used in argentic folk medicine for antibacterial activity. J. Ethnropharmacol, 39(2): 35-47.

[29] Shriner, R.; Fuson, R.; Cartin, D. and Morril, T. 1980. The systematic Identification of Organic Compounds. $8^{\text {th }}$ ed., John Wiley and Sons, New York, USA.

[30] Vogel, A. 1996. Textbook of practical organic chemistry. $5^{\text {th }}$ Edition, Longman.

[31] Huda, A. 2013. Synthesis and Characterization of Some New 1,2,3Triazole, Pyrazolin-5-one and thiazo lidinone Derivatives. J. Al-Nahrain. Un., 16 (1):53-59.

\title{
تحضير وتقدير الفعالية المضادة للبكتريا لبعض معوضات 5-بروموايساتين الجديدة

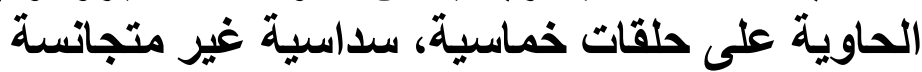

هلى جمال احمد الاعظمي

\author{
سعاد محمد حسين الماجدي \\ قسم الكيمياء، كلية العلوم، جامعة بغداد، بغداد، العراق
}

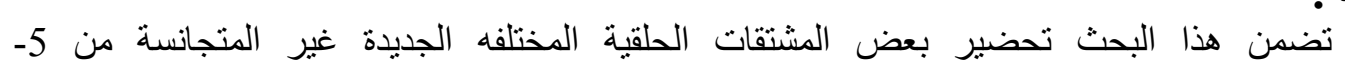

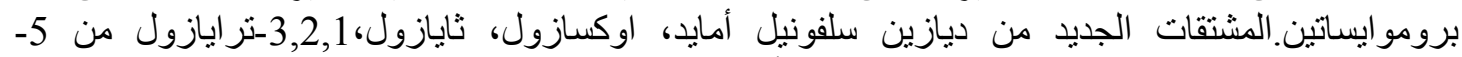

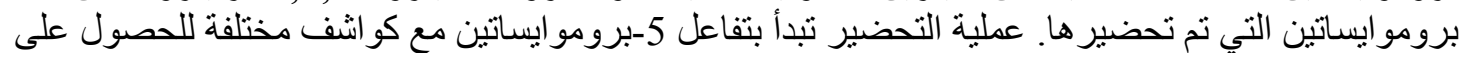

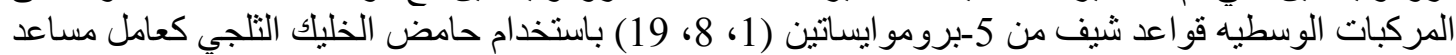

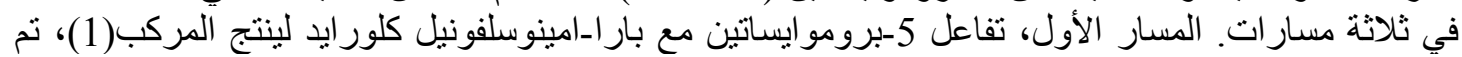

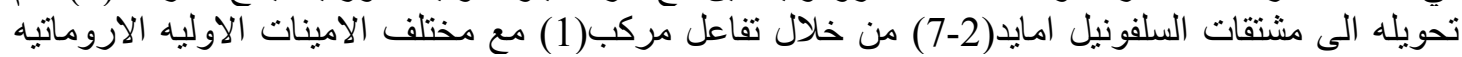

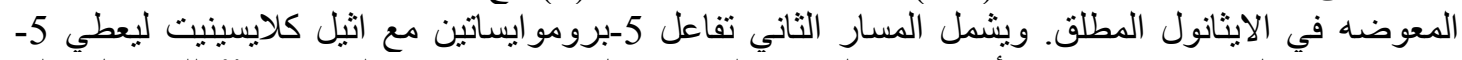

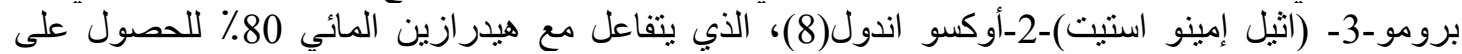

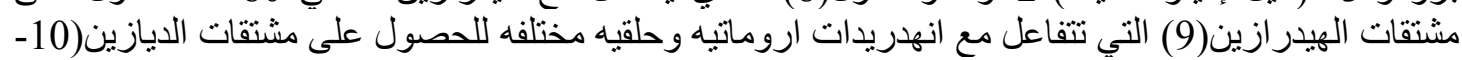

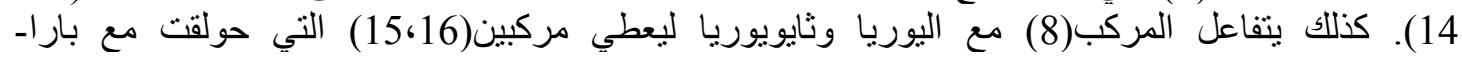

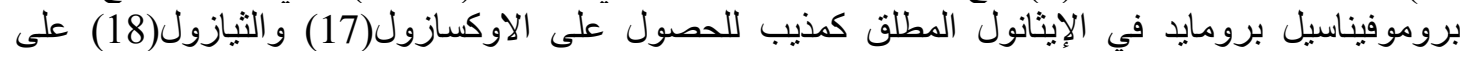

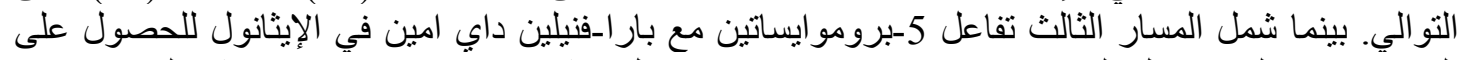

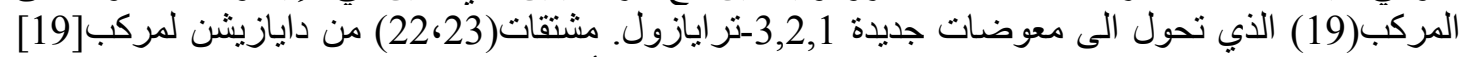

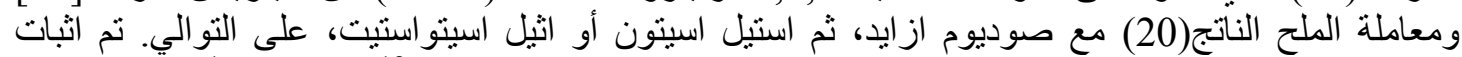

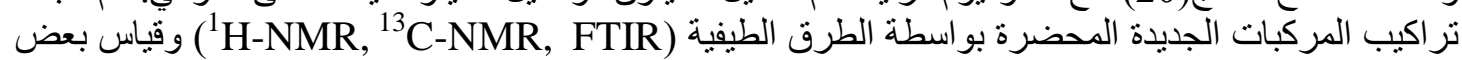

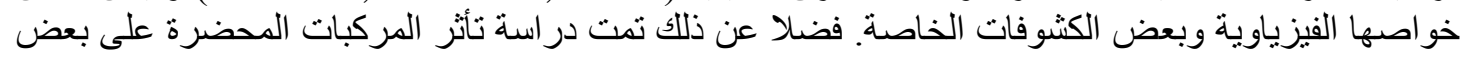

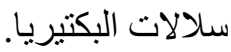
الكلمات المفتاحية: 5-برومو إيساتين، سلفونيل امايد، دايازين، اوكسازول، ثايازول، 3,2,1-نر ايزول، مضاد للبكتريا. 